\title{
Comparative Analysis of Pelletized and Unpelletized Sunflower Husks Combustion Process in a Batch-Type Reactor
}

\author{
Tomasz Turzyński * (D), Jacek Kluska, Mateusz Ochnio and Dariusz Kardaś \\ Institute of Fluid Flow Machinery, Fiszera 14, 80-231 Gdansk, Poland; jacek.kluska@imp.gda.pl (J.K.); \\ mochnio@imp.gda.pl (M.O.); dk@imp.gda.pl (D.K.) \\ * Correspondence: tturzynski@imp.gda.pl
}

\section{check for}

updates

Citation: Turzyński, T.; Kluska, J.; Ochnio, M.; Kardaś, D. Comparative Analysis of Pelletized and Unpelletized Sunflower Husks Combustion Process in a Batch-Type Reactor. Materials 2021, 14, 2484. https://doi.org/10.3390/ ma14102484

Received: 24 March 2021

Accepted: 5 May 2021

Published: 11 May 2021

Publisher's Note: MDPI stays neutral with regard to jurisdictional claims in published maps and institutional affiliations.

Copyright: (c) 2021 by the authors. Licensee MDPI, Basel, Switzerland. This article is an open access article distributed under the terms and conditions of the Creative Commons Attribution (CC BY) license (https:// creativecommons.org/licenses/by/ $4.0 /)$.

\begin{abstract}
This paper describes characteristics of the combustion of sunflower husk (SH), sunflower husk pellets (SHP), and, for comparison, hardwood pellets (HP). The experiments were carried out using a laboratory-scale combustion reactor. A proximate analysis showed that the material may constitute an alternative fuel, with a relatively high heating value $(\mathrm{HHV})$ of $18 \mathrm{MJ} / \mathrm{kg}$. For SHP, both the maximum combustion temperatures $\left(\mathrm{T}_{\mathrm{MAX}}=1110^{\circ} \mathrm{C}\right)$ and the kinetic parameters (temperature front velocity $\mathrm{v}_{\mathrm{t}}=7.9 \mathrm{~mm} / \mathrm{min}$, combustion front velocity $\mathrm{v}_{\mathrm{C}}=8 \mathrm{~mm} / \mathrm{min}$, mass loss rate $\mathrm{v}_{\mathrm{m}}=14.7 \mathrm{~g} / \mathrm{min}$ ) of the process were very similar to those obtained for good-quality hardwood pellets $\left(\mathrm{T}_{\mathrm{MAX}}=1090{ }^{\circ} \mathrm{C}, \mathrm{v}_{\mathrm{t}}=5.4 \mathrm{~mm} / \mathrm{min}, \mathrm{v}_{\mathrm{C}}=5.2 \mathrm{~mm} / \mathrm{min}, \mathrm{v}_{\mathrm{m}}=13.2 \mathrm{~g} / \mathrm{min}\right)$ and generally very different form SH $\left(\mathrm{T}_{\mathrm{MAX}}=840{ }^{\circ} \mathrm{C}, \mathrm{v}_{\mathrm{t}}=20.7 \mathrm{~mm} / \mathrm{min}, \mathrm{v}_{\mathrm{C}}=19 \mathrm{~mm} / \mathrm{min}, \mathrm{v}_{\mathrm{m}}=13.1 \mathrm{~g} / \mathrm{min}\right)$. The analysis of ash from SH and SHP combustion showed that it has good physicochemical properties (ash melting point temperatures $>1500^{\circ} \mathrm{C}$ ) and is safe for the environment. Furthermore, the research showed that the pelletization of $\mathrm{SH}$ transformed a difficult fuel into a high-quality substitute for hardwood pellets, giving a similar fuel consumption density $\left(\mathrm{F}_{\text {out }}=0.083 \mathrm{~kg} / \mathrm{s} \cdot \mathrm{m}^{2}\right.$ for SHP and $0.077 \mathrm{~kg} / \mathrm{s} \cdot \mathrm{m}^{2}$ for $\mathrm{HP}$ ) and power output density $\left(\mathrm{P}_{\rho}=\mathrm{MW} / \mathrm{m}^{2}\right.$ for $\mathrm{SHP}$ and $1.5 \mathrm{MW} / \mathrm{m}^{2}$ for HP).
\end{abstract}

Keywords: combustion; sunflower husk; hardwood; combustion velocity

\section{Introduction}

Biomass wastes, as compared to fossil fuels, wood, and wheat straw, may be an interesting alternative renewable energy resource. However, these fuels, in terms of exploitation of their potential, present a challenge for conventional technological solutions. The constant increase in the quantity of biomass-derived waste materials has created the need for an industrial sector to further develop industrial thermal waste management technology based on these types of fuel. One of the most promising animal-derived waste energy sources is poultry litter, as described by [1,2]. Furthermore, an experimental investigation of horse manure combustion has been reported by [3]. Other types of waste, such as sewage sludge, have also been the subject of research [4-7]. Rice husks are another interesting source of biomass waste. The characteristics of pine wood and rice husk combustion, including temperature and emission measurements, were presented by [8]. According to the literature, many kinds of non-wood biomass are potential alternative energy sources. These fuels also come in different forms, including shells, grains, pits, and grasses, which can often lead to various problems such as slagging, deposit formation, decrease in combustion temperature, or fluctuation in the fuel consumption [9]. Acknowledging that one of the most common solutions used for the domestic combustion of fuels is small fixed-grate furnace units [10], the operational problem related to the combustion process on a grate becomes even more significant. For this reason, the conversion of waste biomass fuel into a pelletized form has become the subject of intense research and many scientific publications.

Sunflower husks, especially those subjected to the pelletization process, seem to be a resource that could successfully supplement traditional wood pellets. This work 
presents and compares the results of the combustion of sunflower husk (SH) and pelletized sunflower husk (SHP). The pelletization process enables increasing the energy density of the fuel, and can therefore generally improve the quality of the product and increase control over the combustion process.

The possibility of pelletization of rice husks and the characteristics of their combustion were reported by [11]. It had been noted previously that the reduction of fuel size by pelletization leads to an increase in the fuel bulk density and provides fuel size reduction before transportation [12]. This aspect was also presented by [13], Ref. [11] reported and characterized the pelletization of rice husk and wheat straw, while [14] presented a characterization of the pelletization process of poplar and pine sawdust. Ref. [15] showed that the operational cost of pelletization of waste fuels such as alfalfa, sawdust, and pig and chicken feed wood waste is in fact highly variable, ranging from 8 to $75 \mathrm{kWh} /$ tonne depending on the material.

Sunflower husks have also been the subject of many studies, concerning various applications. According to the literature, the sunflower is very commonly grown on every continent, with a total production of 47 million tonnes annually [16]. The weight of the sunflower husk amounts to about $40-60 \%$ of the produced seeds. For this reason, sunflower husk is a promising source of pellet production, amounting to about 240,000 tonnes per year in Ukraine, while worldwide agriculture generates over 10 million tonnes of sunflower seed [17]. According to [18] sunflower production in Croatia reached $2.77 \mathrm{t} / \mathrm{ha}$ and indicated sunflower husk as a potential high-quality biomass fuel.

The possibility of using ash from sunflower husk in the ceramic industry was described by [19], while [20] presented the use of sunflower husk in the iron ore sintering process. In turn, Ref. [21] presented the characteristics of sunflower husk as a filler for epoxy-based composites, with analysis of the mechanical properties. However, there is a lack of studies describing the combustion process of sunflower husk and its potential as a heat source.

The characteristics of sunflower husks and sunflower husk pellets as fuels for cofiring with brown coal in energy boilers were presented by [22]. Moreover, computational analysis, using CHEMKIN-PRO (Ansys, Canonsburg, PA, USA), and an experimental study using thermal analysis (TGA) were used by $[23,24]$ to analyze sunflower husk pellet and pine wood combustion and their co-combustion with oats.

This work presents a characterization of the dynamics of the direct combustion of pure sunflower husk (SH) and pelletized sunflower husk (SHP), including temperature characteristics, averaged maximum temperatures $\left(\mathrm{T}_{\mathrm{MAX}}\right)$, and averaged flame temperatures $\left(\mathrm{T}_{\text {flame }}\right)$, as well as combustion kinetics, including temperature front velocity $\left(\mathrm{v}_{\mathrm{t}}\right)$ and combustion front velocity $\left(\mathrm{v}_{\mathrm{c}}\right)$. For this end, an innovative experimental stand was prepared, allowing for simultaneous temperature measurement inside and above the combusting fuel bed, as well as visual observation of the process. It also includes a characterization of the energy balance, including mass loss rate, as well as two original parameters proposed by the authors: fuel consumption density $\left(\mathrm{F}_{\text {out }}\right)$ and power output density $\left(\mathrm{P}_{\rho}\right)$. These new intertwined parameters allow for a direct comparison between vastly different fuel types and provide guidance towards designing proper, dedicated combustion devices or grate furnaces.

\section{Materials and Methods}

\subsection{Materials}

Pelletized sunflower husks were made using a flat die pellet-making machine. The nominal size of the pellets was $8 \mathrm{~mm}$ in diameter and about $10 \mathrm{~mm}$ in length. Pellets were made without the use of any external additives.

Proximate and ultimate analyses of sunflower husk, sunflower husk pellets, and hardwood pellets are presented in Table 1. Analyses were carried out using a S8 TIGER $1 \mathrm{~kW}$-High Performance Wavelength Dispersive XRF spectrometer (Bruker Scientific Instruments, Billerica, MA, USA) and an Organic Elemental Analyzer Flash 2000 CHNS/O (Thermo Scientific, Waltham, MA, USA). The moisture content was determined using a 
Moisture Analyzer MAX 50 (Radwag, Radom, Poland; max capacity 50 g, readout accuracy $0.0001 \%$ ), and calorific value was determined using a calorimeter (EkotechLAB, Gdańsk, Poland).

Table 1. Proximate and ultimate analysis of sunflower husk and hardwood pellets.

\begin{tabular}{cccc}
\hline Parameter & $\begin{array}{c}\text { Sunflower } \\
\text { Husk }\end{array}$ & $\begin{array}{c}\text { Sunflower Husk } \\
\text { Pellets }\end{array}$ & $\begin{array}{c}\text { Hardwood } \\
\text { Pellets }\end{array}$ \\
\hline HHV (MJ/kg) & 18.11 & 19.18 & 19.60 \\
Moisture (wt\%), as delivered & 9.61 & 10.71 & 6.1 \\
Proximate (wt.\% ) $^{\text {a }}$ & & & 76.3 \\
Volatiles & 82.7 & 83.59 & 21.4 \\
Fixed carbon & 16.1 & 14.51 & 2.3 \\
Ash & 1.2 & 1.9 & 48.50 \\
Ultimate (wt.\% $\left.{ }_{\mathrm{db}}\right)^{\text {a }}$ & 46.21 & 43.38 & 5.30 \\
$\mathrm{C}$ & 6.06 & 6.62 & 45.56 \\
$\mathrm{O}$ & 46.58 & 48.81 & 0.40 \\
$\mathrm{~N}$ & 0.88 & 1.19 &
\end{tabular}

$\mathrm{a} \mathrm{db}=$ oven-dry basis.

To evaluate the combustion characteristics of these fuels, sunflower husk and sunflower husk pellets (shown in Figure 1) were compared with commercial hardwood pellets ( $8 \mathrm{~mm}$ in diameter and $10-15 \mathrm{~mm}$ in length). The measured bulk density of HP was $669 \mathrm{~kg} / \mathrm{m}^{3}$, while for SHP and SH the respective values were $478 \mathrm{~kg} / \mathrm{m}^{3}$ and $139 \mathrm{~kg} / \mathrm{m}^{3}$. All of the materials had a similar HHV value and composition (the analysis of HP shows a slightly higher fixed carbon content at the cost of the volatiles fraction).

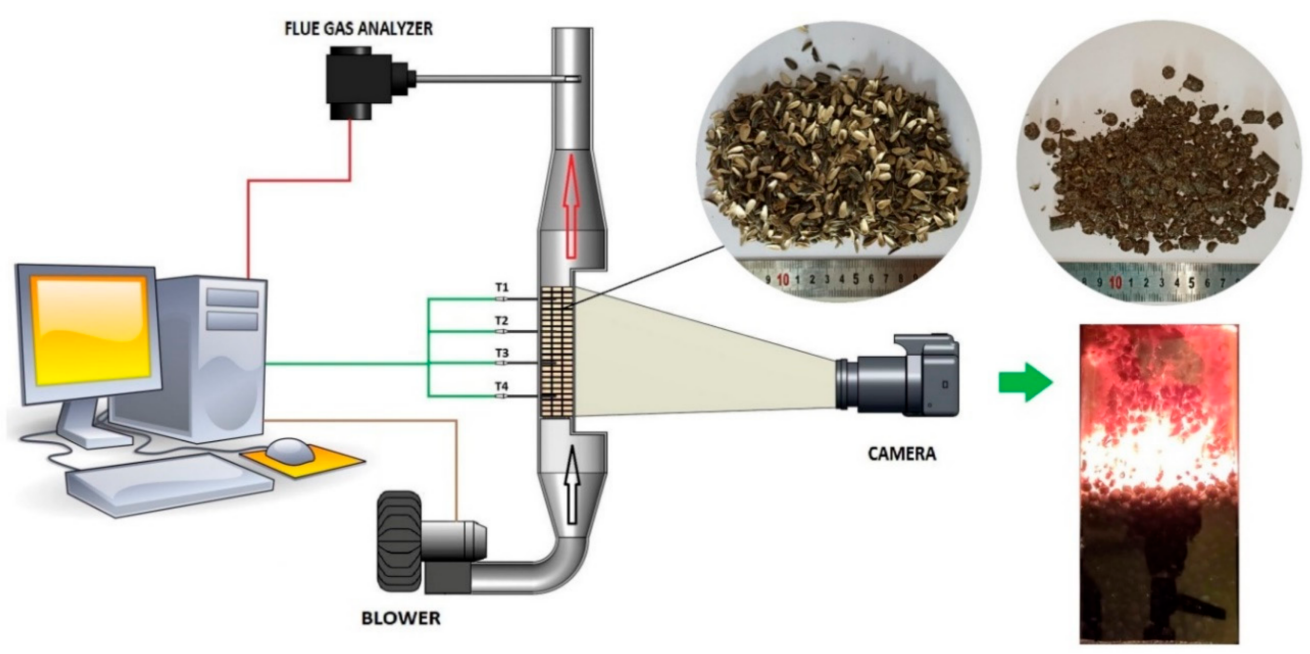

Figure 1. Test stand for the combustion process.

\subsection{Combustion Procedure}

Experiments were carried out using a small-scale batch combustion reactor, specially designed for simulating the combustion process on a grate, and equipped with an air supply, a temperature measurement and recording system, and an exhaust gas analyzer (Figure 1). The combustion process in the reactor progressed from the top of the packed bed to the bottom, along a vertical trajectory. The combustion reactor and exhaust tube were insulated with $3 \mathrm{~cm}$ insulating rock wool. The laboratory reactor's combustion chamber had a halfcylinder shape, with a diameter of $80 \mathrm{~mm}$ and height of $200 \mathrm{~mm}$. The front, flat wall of the combustion chamber was covered with heat resistant glass, enabling visual recording of the process (camera in Figure 1). Four K-type thermocouples (T1-T4, measurement range $-40-1200{ }^{\circ} \mathrm{C}$, class 1 , shielding material-AISI 314 (Termoaparatura Wrocław, Poland)) were located horizontally above the grate at equal distances from each other $(40 \mathrm{~mm})$ and from the curved wall of the combustion chamber $(25 \mathrm{~mm})$. A grate with 24 holes, each of 
$4 \mathrm{~mm}$, was placed at the bottom of the combustion chamber. Temperature measurements were taken at $30 \mathrm{~s}$ intervals. The results obtained for the temperature distribution inside the fuel bed during combustion enabled determination of the temperature front velocity $\left(v_{t}\right)$, as well as the maximum combustion temperature $T_{M A X}$ and flame temperature $T_{\text {flame }}$. In a batch-type combustion reactor, given that the process is stable, the temperature front travels through the fuel bed at a certain constant rate. This rate is called the temperature front velocity $\left(\mathrm{v}_{\mathrm{t}}\right)$ and can be calculated using the data provided by the thermocouples (T1-T4). In this study, the researchers focused on the velocity at which the temperature $400{ }^{\circ} \mathrm{C}$ "traveled" through the combusting bed. When the distance traveled by the $400{ }^{\circ} \mathrm{C}$ front (based on the known distances between thermocouples) is plotted against time, the temperature front velocity $v_{t}$ can be defined as the slope of a linear approximation of these data. For each kind of fuel combusted inside the reactor, the process was repeated three (SHP and HP) or four (SH) times to verify the repeatability of the experiment.

Moreover, the combustion front velocity $\mathrm{v}_{\mathrm{c}}$ was determined using the methodology previously described by [25]. This original method requires the visual capture of the combustion process inside the reactor at known time intervals (30 s). For this purpose the heat-resistant measurement window was utilized. A camera captures the combustion process in a series of images; then a software tool acquires a color palette from an image not containing any flame or embers, and subtracts that palette from an image of an actual experiment. The result is an image containing only the glow from the combustion process. The location of the lowest pixel visible on the image is the location of the combustion front at that moment in time. The slope of a linear approximation of these locations over time is called the combustion front velocity $\mathrm{v}_{\mathrm{c}}$. This parameter provides information about whether or not the $\mathrm{v}_{\mathrm{c}}$ parameter was calculated correctly and combined with temperature profiles can be used to determine the amount of afterburn occurring for each fuel. During each experiment, the weight loss of SH, SHP, or HP was monitored and recorded.

In the experiments, the total mass of the sample inserted into the reactor, according to bulk density, was approximately $500 \mathrm{~g}$ for HP, $350 \mathrm{~g}$ for SHP, and $100 \mathrm{~g}$ for SH. Each experiment was conducted several times ( 3 or 4 ) to ensure repeatability. The flow rate of the air supplied for the combustion for each kind of fuel was adjusted so that the amount of carbon monoxide $(\mathrm{CO})$ in the flue gases was minimal and the process occurred in over-stoichiometric conditions $(\lambda>1)$.

To ignite the sample, the surface of the bed was covered with a layer of highly volatile cellulose cubes. After air was supplied from the bottom of the reactor, an open flame was applied to the cubes. Upon obtaining a stable combustion process of the fuel bed, signified by a constant mass loss rate, the experimental investigation was conducted.

\section{Results and Discussion}

\subsection{Temperature Characteristics}

The following paragraphs present a comparison of the combustion processes of sunflower husk, sunflower husk pellets, and wood pellets. Analysis of the experimental data (Figure 2) places the averaged maximum temperatures ( $\left.\mathrm{T}_{\mathrm{MAX}}\right)$ during the combustion process at $840{ }^{\circ} \mathrm{C}$ for sunflower husk, $1110^{\circ} \mathrm{C}$ for sunflower husk pellets, and $1090^{\circ} \mathrm{C}$ for wood pellets. Similarly, the averaged flame temperatures $\left(\mathrm{T}_{\text {flame }}\right)$ during the combustion process were approximately $800^{\circ} \mathrm{C}$ for sunflower husk pellets and $940{ }^{\circ} \mathrm{C}$ for wood pellets. However, the sunflower husk combustion process did not produce a stable flame temperature, suggesting that the process itself was not stable. Closer inspection of the temperature profiles seemed to corroborate this observation. The temperature spikes for each batch were not evenly distributed during the experiment, which implies that the combustion process occurred at different, randomized rates for each experiment. This was probably because of the relatively low bulk density of the fuel itself. During combustion, individual husks became light enough for the air flow to cause mixing of the bed in the reaction zone, thus introducing irregularities in the bed and affecting the speed of the process. In some instances, light, unburnt particles were even carried out of the reactor by the air flow. On 
the other hand, for both SHP and HP the combustion process progressed at a constant rate, and the result was repeatable for each batch. Nevertheless, the temperature spikes corresponding to SHP did not align as well as the temperature spikes for HP. In addition, the difference between maximum temperature and flame temperature for SHP was higher than for HP, which suggests that using SHP as a primary fuel may result in lower thermal parameters for the combustion device and heat exchanger. Notably, a lower operational load of the boiler using SHP was also independently corroborated by [26].

a)

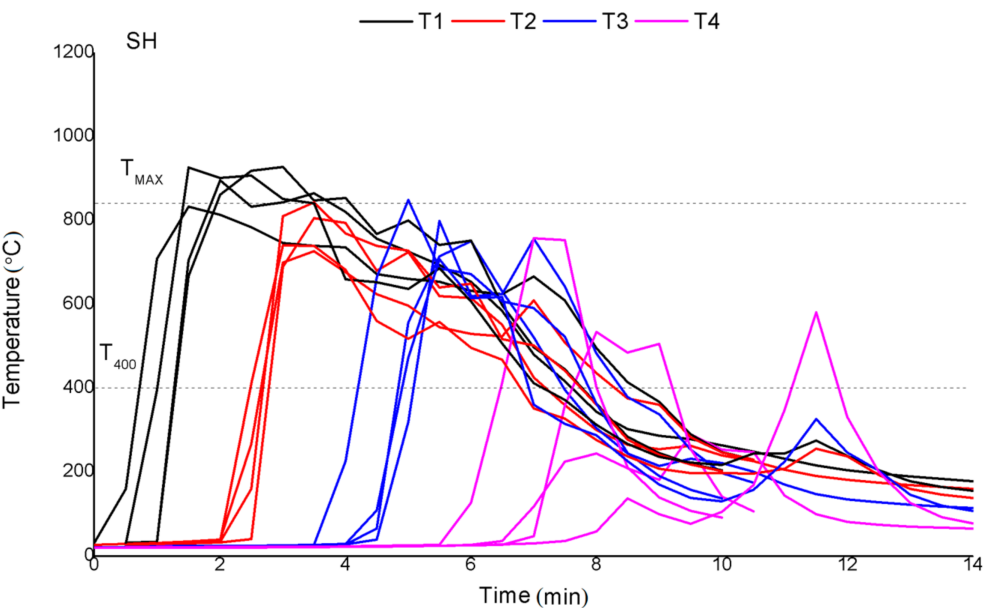

b)

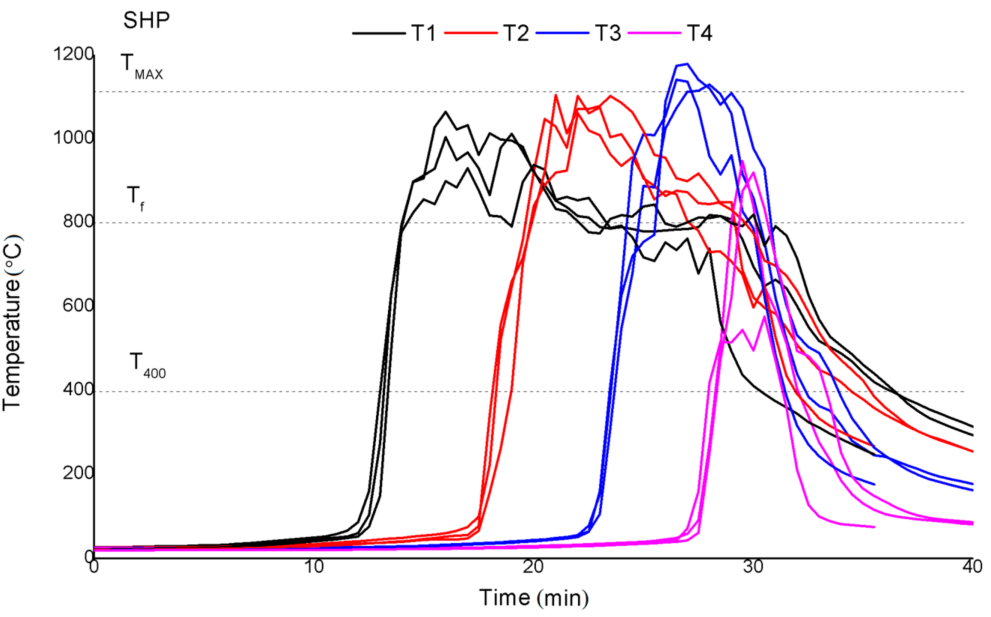

c)

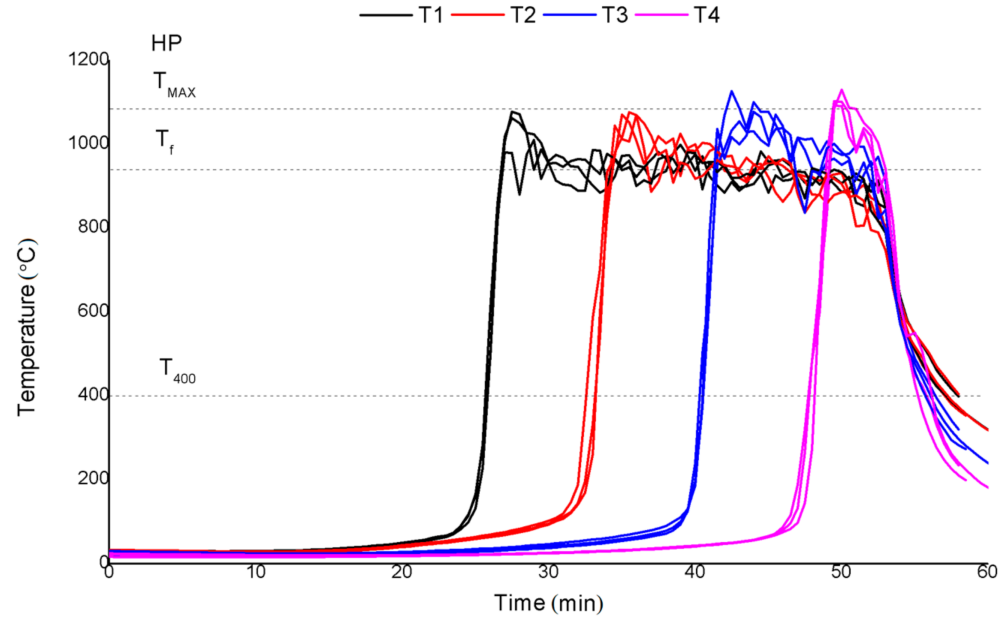

Figure 2. Temperature characteristics for combustion of (a) sunflower husk, (b) sunflower husk pellets, and (c) hardwood pellets. 


\subsection{Combustion Kinetics}

\subsubsection{Temperature Front Velocity and Combustion Front Velocity}

In a bed composed of HP the temperature front traveled the slowest, at a rate of $5.4 \mathrm{~mm} / \mathrm{min}$. The value was slightly higher for SHP $(7.9 \mathrm{~mm} / \mathrm{min})$ and highest for SH $(20.7 \mathrm{~mm} / \mathrm{min})$. Furthermore, the values of $\mathrm{v}_{\mathrm{t}}$ calculated for each batch differed the most for $\mathrm{SH}$, ranging from 17.3 to $22.9 \mathrm{~mm} / \mathrm{min}$. A bed composed of SH burned out the fastest, but in a random and highly unstable manner; therefore the $\mathrm{v}_{t}$ value obtained from the experiment was also highly inaccurate, although it is somewhat informative.

The combustion front velocities for HP and SHP were $5.2 \mathrm{~mm} / \mathrm{min}$ and $8.0 \mathrm{~mm} / \mathrm{min}$, respectively; corresponding with the temperature front velocities $\mathrm{v}_{\mathrm{t}}$ obtained from the temperature measurements $(5.7 \mathrm{~mm} / \mathrm{min}$ and $7.9 \mathrm{~mm} / \mathrm{min})$. The values of $\mathrm{v}_{\mathrm{c}}$ for $\mathrm{SH}$, however, again varied widely between batches, ranging from $15 \mathrm{~mm} / \mathrm{min}$ to $22.4 \mathrm{~mm} / \mathrm{min}$, with an average of $19 \mathrm{~mm} / \mathrm{min}$. The results showed that the combustion front velocity $\left(\mathrm{v}_{\mathrm{c}}\right)$ obtained using the described methodology corresponded to the measured temperature front velocity $\left(\mathrm{v}_{\mathrm{t}}\right)$.

\subsubsection{Mass Loss}

The mass loss of the sample during the combustion process was recorded using a laboratory scale (Radwag APP 30/2C/1, Radom, Poland (Radwag, maximum load $30 \mathrm{~kg}$, measurement accuracy $0.1 \mathrm{~g}$, linearity $\pm 0.3 \mathrm{~g}$ )). Figure 3 shows how the mass of a sample changed over time during the experiment. As mentioned above, each batch was ignited using a layer of flammable material; therefore, the character of mass loss at the early stages of the experiment mainly represented the combustion process of the ignition material. After the ignition, the process of mass loss became stable (linear). Similarly to $\mathrm{v}_{\mathrm{t}}$ and $\mathrm{v}_{\mathrm{c}}$, the mass loss rate $\left(\mathrm{v}_{\mathrm{m}}\right)$ was calculated as the slope of a linear approximation of the mass loss data over time, taken for a stable combustion process. Both HP and SHP samples produced fairly comparable, repeatable results, while $\mathrm{SH}$ samples produced highly diverse results: the ranges were $12.9-13.3 \mathrm{~g} / \mathrm{min}$ for HP, $12.8-15.8 \mathrm{~g} / \mathrm{min}$ for SHP, and $8.5-15.7 \mathrm{~g} / \mathrm{min}$ for $\mathrm{SH}$. However, the averaged $\mathrm{v}_{\mathrm{m}}$ value appeared to be fairly similar for all fuel types: $13.2 \mathrm{~g} / \mathrm{min}$ for HP, $14.7 \mathrm{~g} / \mathrm{min}$ for SHP, and $13.1 \mathrm{~g} / \mathrm{min}$ for SH.

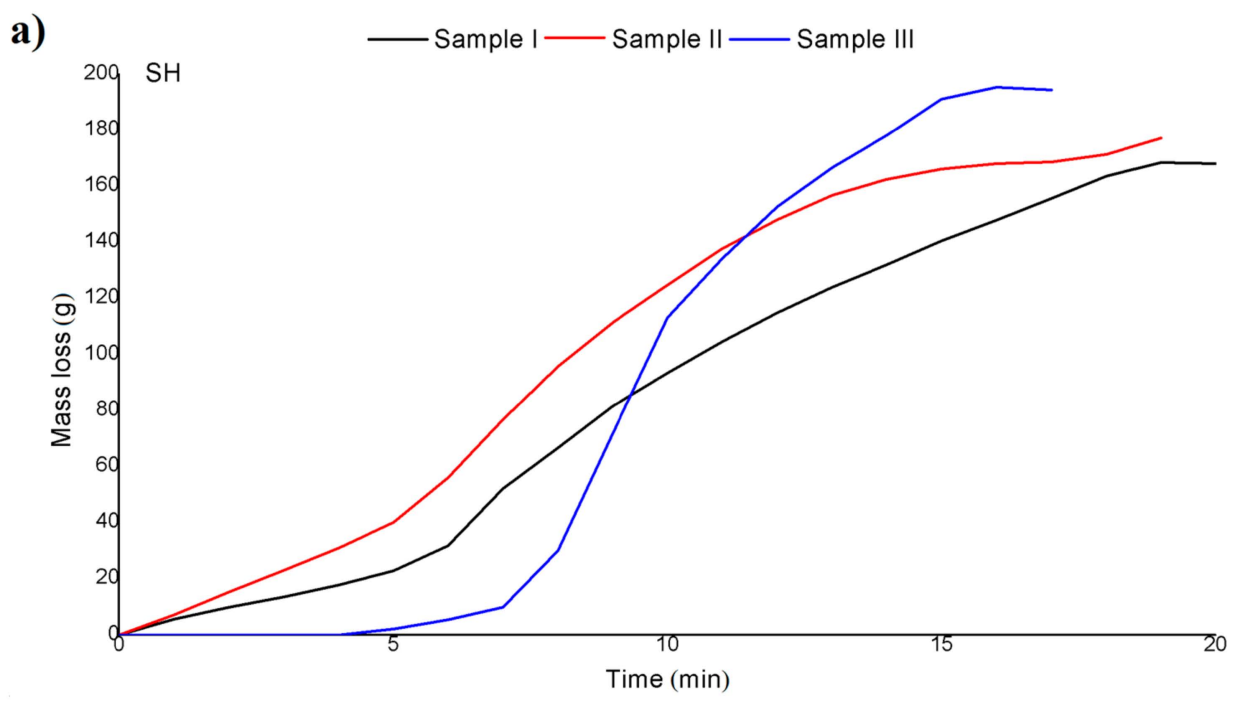

Figure 3. Cont. 
b)

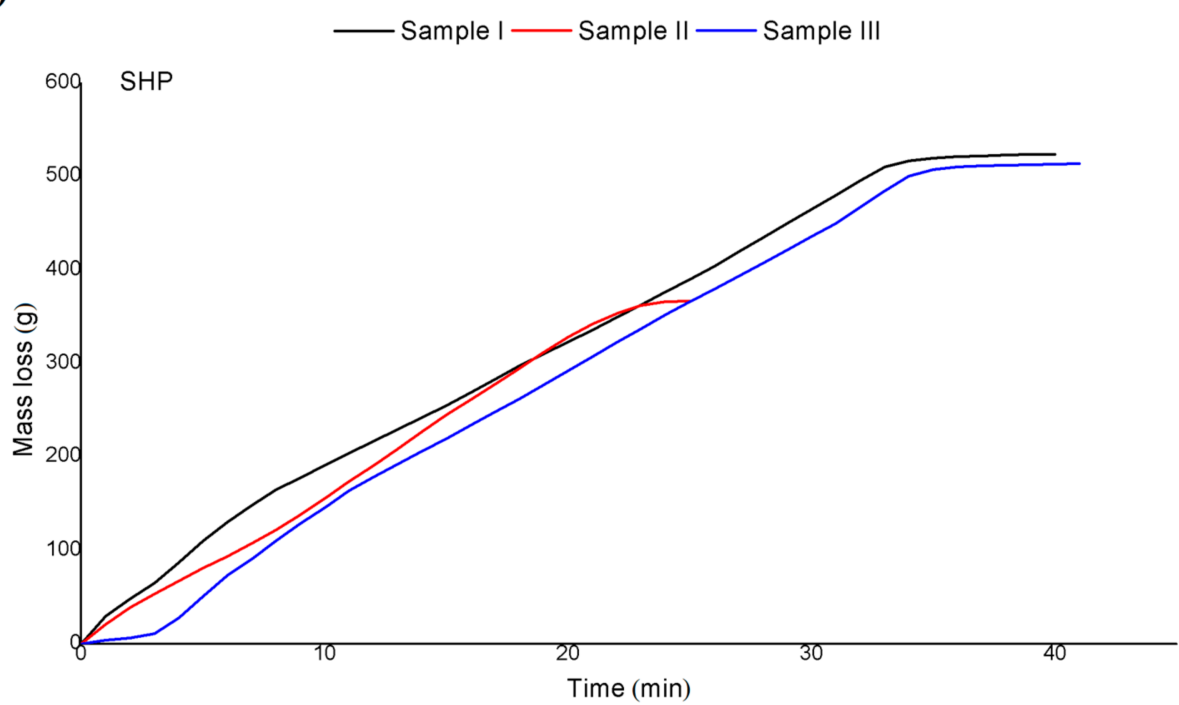

c)

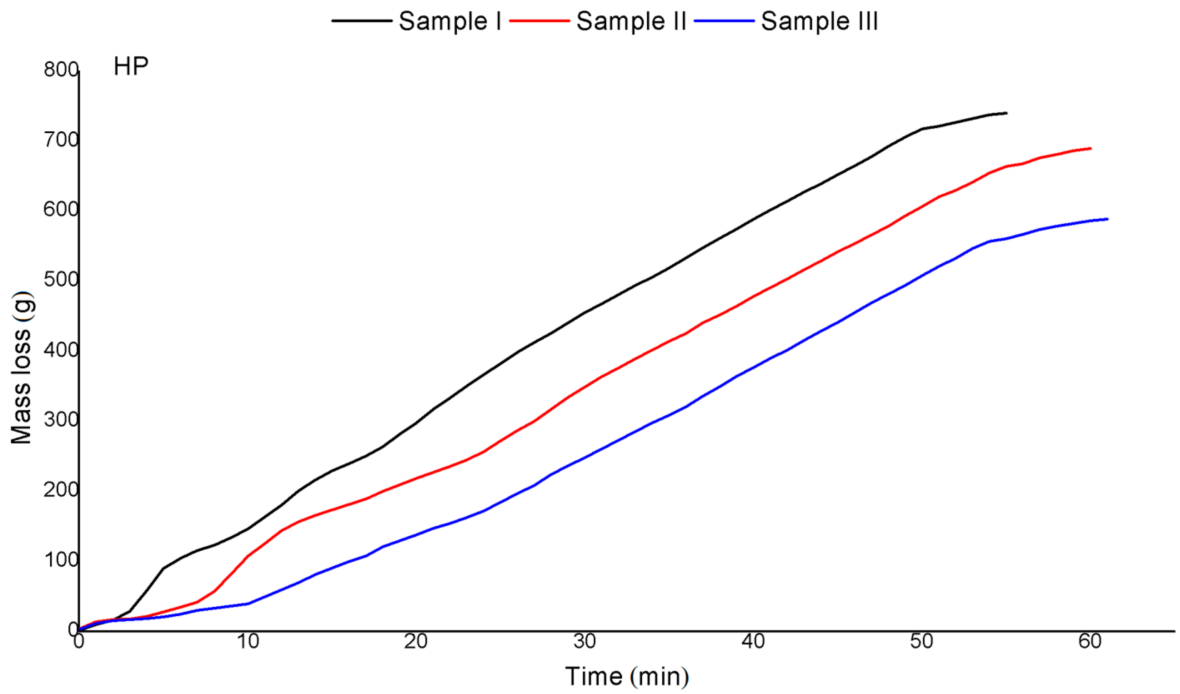

Figure 3. Mass loss rate during combustion of (a) sunflower husk, (b) sunflower husk pellets, and (c) hardwood pellets.

\subsection{Energy Balance}

Results of calorific analysis of the samples are presented in Table 2. The HHV values of SHP and HP are very similar, while for pure SH the value is slightly lower. On the other hand, the bulk densities of the fuel types are very different, ranging from $139 \mathrm{~kg} / \mathrm{m}^{3}$ for SH, through $478 \mathrm{~kg} / \mathrm{m}^{3}$ for SHP, to $669 \mathrm{~kg} / \mathrm{m}^{3}$ for HP. Other studies on sunflower husk pellets have shown various SHP bulk densities ([27], $838 \mathrm{~kg} / \mathrm{m}^{3}$, Ref. [28], $540 \mathrm{~kg} / \mathrm{m}^{3}$, Ref. [26], $529 \mathrm{~kg} / \mathrm{m}^{3}$ ), which the pelletization process can significantly alter, depending on the size of the die and the compression rate. 
Table 2. Parameters of the operation of the batch combustion reactor using sunflower husk, sunflower husk pellets, and hardwood pellets.

\begin{tabular}{cccc}
\hline Parameter & Sunflower Husk & Sunflower Husk Pellets & Wood Pellets \\
\hline $\mathrm{HHV}_{\mathrm{avr}}(\mathrm{MJ} / \mathrm{kg})$ & 18.11 & 19.18 & 19.60 \\
$\mathrm{~V}_{\mathrm{c}}(\mathrm{mm} / \mathrm{min})$ & 19.0 & 8.0 & 5.2 \\
$\mathrm{~V}_{\mathrm{m}}(\mathrm{g} / \mathrm{min})$ & 13.2 & 14.7 & 13.1 \\
$\rho_{\text {bulk }}\left(\mathrm{kg} / \mathrm{m}^{3}\right)$ & 139 & 478 & 669 \\
$\mathrm{~T}_{\mathrm{MAX}}\left({ }^{\circ} \mathrm{C}\right)$ & 840 & 1110 & 1090 \\
$\mathrm{~T}_{\text {flame }}\left({ }^{\circ} \mathrm{C}\right)$ & - & 800 & 940 \\
$\mathrm{~F}_{\text {out }}\left(\mathrm{kg} / \mathrm{s} \cdot \mathrm{m}^{2}\right)$ & 0.072 & 0.083 & 0.077 \\
$\mathrm{P}_{\rho}\left(\mathrm{MW} / \mathrm{m}^{2}\right)$ & 1.30 & 1.59 & 1.50 \\
\hline
\end{tabular}

To characterize the energy output of the reactor, two original parameters, the fuel consumption density $\mathrm{F}_{\text {out }}$ and power output density $\mathrm{P}_{\rho}$, were defined as:

$$
\begin{gathered}
\mathrm{F}_{\text {out }}=\frac{\mathrm{V}_{\mathrm{m}}}{\mathrm{A}_{\mathrm{g}}} \\
\mathrm{P}_{\rho}=\mathrm{HHV}_{\mathrm{avr}} \cdot \mathrm{F}_{\text {out }}
\end{gathered}
$$

where $A_{g}\left(m^{2}\right)$ is the surface area of the grate.

The fuel consumption density $\mathrm{F}_{\text {out }}$ describes how much mass of the fuel a square meter of a grate combusts every second (Equation (1)), while the power output density $\mathrm{P}_{\rho}$ shows how much power is released from that same square meter (Equation (2)). Considering that the $\mathrm{v}_{\mathrm{m}}$ value is highest for SHP, this means that SHP also has the highest fuel consumption density $\left(\mathrm{F}_{\text {out }}=0.083 \mathrm{~kg} / \mathrm{s} \cdot \mathrm{m}^{2}\right)$ and power output density $\left(\mathrm{P}_{\rho}=1.59 \mathrm{MW} / \mathrm{m}^{2}\right)$. The results show that the pelletization process of $\mathrm{SH}$ transformed a difficult fuel into a high-quality substitute for hardwood pellets, giving a similar fuel consumption density $\left(\mathrm{F}_{\text {out }}\right)$ and power output density $\left(\mathrm{P}_{\rho}\right)$.

\subsection{Analysis of Bottom Ash}

Table 3 presents the inorganic compounds identified in the ash from the combustion processes of sunflower husk and sunflower husk pellets. Characteristics of ash composition were carried out using an S8 TIGER $1 \mathrm{~kW}$-High Performance Wavelength Dispersive XRF spectrometer (Bruker Scientific Instruments, Billerica, MA, USA). Analysis of the ash from SH and SHP combustion showed that it has good physicochemical properties and is safe for the environment. Moreover, ash samples from SH and SHP had similar contents of inorganic compounds. These included potassium oxide (33\% for the $\mathrm{SH}$ ash sample and $35 \%$ for SHP), calcium oxide ( $25 \%$ for SH and $37 \%$ for SHP), phosphorus pentoxide ( $14 \%$ for SH and $5 \%$ for SHP), and magnesium oxide (13\% for SH and $11 \%$ for SHP). According to the literature, differences in the composition of ash from sunflower husk and sunflower husk pellets may be caused by additives used during the pelleting process [22]. The obtained results of ash composition were also similar to results presented by [28] and showed that ash from biofuels may be used as a soil amendment. In this case it is important to analyze the pollutants content, which is related to environmental protection. In turn, Ref. [19] showed the possibility of utilizing a similar ash from sunflower husks to develop new glass/crystal materials. 
Table 3. Inorganic compounds identified in ash from the combustion of sunflower husk and sunflower husk pellets.

\begin{tabular}{ccc}
\hline Compound & Sunflower Husk & Sunflower Husk Pellets \\
\hline $\mathrm{K}_{2} \mathrm{O}$ & 33.97 & 35.14 \\
$\mathrm{CaO}$ & 25.50 & 37.40 \\
$\mathrm{P}_{2} \mathrm{O}_{5}$ & 14.58 & 5.38 \\
$\mathrm{MgO}$ & 13.92 & 11.73 \\
$\mathrm{SO}_{3}$ & 5.14 & 5.66 \\
$\mathrm{SiO}_{2}$ & 3.94 & 1.92 \\
$\mathrm{Fe}_{2} \mathrm{O}_{3}$ & 1.49 & 0.99 \\
$\mathrm{Al}_{2} \mathrm{O}_{3}$ & 0.77 & 0.21 \\
$\mathrm{Cl}$ & 0.21 & 0.85 \\
$\mathrm{MnO}$ & 0.20 & 0.20 \\
$\mathrm{SrO}$ & 0.1 & 0.09 \\
$\mathrm{CuO}$ & 0.08 & 0.07 \\
$\mathrm{ZnO}$ & 0.08 & 0.11 \\
\hline
\end{tabular}

In addition, the characteristic temperatures of the bottom ash were determined (according to the methodology of PN-G-04535:1982). The results are given in Table 4. The obtained characteristic temperatures were further compared with those of other biomass fuels for which the DIN 51730 was applied [29,30]. A low plasticization temperature of the ash can lead to sticking to the grate or slagging. Moreover, low spherical and hemispherical temperatures can lead to the sticking of fly ash to the boiler heat exchangers. However, for SHP, both the melting temperature and the spherical and hemispherical temperatures were quite high, comparable even to the values for pine wood or willow wood. The results show that ash from sunflower husk and from sunflower husk pellets is characterized by high melting temperatures, comparable to those of high-quality fuels. Interestingly, the initial deformation temperature was lower by $130^{\circ} \mathrm{C}$ for $\mathrm{SH}$ than for SHP, which consists basically of the same material. The pelletization of the sunflower husk led to an increase in the initial deformation temperature, from $970{ }^{\circ} \mathrm{C}$ for $\mathrm{SH}$ to $1100^{\circ} \mathrm{C}$ for SHP. Additionally, the acquired temperatures regarding SHP ash correspond with an independent study by [28].

Table 4. Properties of ash from sunflower husk and sunflower husk pellets and from various types of biomass $[29,30]$.

\begin{tabular}{ccccc}
\hline Ash & $\begin{array}{c}\text { Initial } \\
\text { Deformation } \\
\text { Temperature }\left({ }^{\circ} \mathbf{C}\right)\end{array}$ & $\begin{array}{c}\text { Spherical } \\
\text { Temperature } \\
\left({ }^{\circ} \mathbf{C}\right)\end{array}$ & $\begin{array}{c}\text { Hemispherical } \\
\text { Temperature } \\
\left({ }^{\circ} \mathbf{C}\right)\end{array}$ & $\begin{array}{c}\text { Fluid } \\
\text { Temperature } \\
\left({ }^{\circ} \mathbf{C}\right)\end{array}$ \\
\hline Sunflower husk & 970 & $>1500$ & $>1500$ & $>1500$ \\
Sunflower husk pellets & 1100 & 1490 & $>1500$ & $>1500$ \\
Pine wood & 1190 & 1200 & 1220 & 1280 \\
Wheat straw & 850 & 1040 & 1120 & 1320 \\
Rice straw & 860 & 980 & 1100 & 1220 \\
Willow wood & 1380 & 1540 & 1550 & 1560 \\
\hline
\end{tabular}

\section{Conclusions}

This paper has provided a comparative characterization of the batch combustion, on a grate, of sunflower husk, sunflower husk pellets, and hardwood pellets. The experimental research used an innovative laboratory-scale reactor and incorporated several original parameters proposed by the authors: temperature front velocity $\mathrm{v}_{\mathrm{t}}$, combustion front velocity $v_{c}$, fuel consumption density $F_{\text {out }}$, and power output density $P_{\rho}$. These parameters provide vital data regarding fuel behavior on a grate and can be used to design an optimal combustion method for a particular fuel.

The analysis shows that sunflower husk may constitute a good-quality alternative fuel, with a relatively high heating value. It was shown that for sunflower husk pellets, the maximum combustion temperatures and the kinetic parameters of the combustion 
process are very similar to those obtained for good-quality hardwood pellets. On the other hand, the combustion of unpelletized sunflower husk produced a lower average maximum temperature and average flame temperature, and it was found that the combustion process was not stable, due to the relatively low bulk density of the fuel and irregularities in the bed, which affected the speed of the process, and the lifting and carrying of light particles by the air flow. It was concluded that the pelletization of sunflower husk, despite the initial costs, transformed a difficult fuel into a high-quality substitute for hardwood pellets; giving similar fuel consumption density and power output density. Furthermore, the pelletization process approximately triples the bulk density of the fuel, which is very important for storage and logistics. The analysis of ash from SH and SHP combustion showed that it has good physicochemical properties and is safe for the environment. Ash from sunflower husk and from sunflower husk pellets is characterized by high melting temperatures, comparable to the value for pine wood, and higher than for wheat straw or rice straw.

Sunflower husk in a pelletized form presents itself as a promising fuel. This article however focuses on a laboratory scale combustion process with fairly restrictive assumptions. Further research, due to the importance of legislation and environmental protection, should include a standard fixed grate pellet burner and a boiler unit. Such an experimental stand would provide more information regarding particle emission, flue gas composition, ash production, and fouling of the grate/heat exchanger. It would be possible to determine the impact of this fuel on the overall performance of the unit compared with standard hardwood pellets. Moreover, some insight into the pellet production process would also be desirable, as the quality of the fuel, especially its bulk density and rigidity, could surely be improved.

Author Contributions: Conceptualization, T.T., J.K., M.O.; methodology, T.T., J.K.; formal analysis, T.T. and D.K.; investigation, T.T., J.K.; writing—original draft preparation, T.T. and J.K.; writing-review and editing, T.T., J.K., M.O., D.K.; supervision, D.K. All authors have read and agreed to the published version of the manuscript.

Funding: This research received no external funding.

Institutional Review Board Statement: Not Applicable.

Informed Consent Statement: Not Applicable.

Data Availability Statement: The data presented in this study are available upon request from the corresponding author.

Conflicts of Interest: The authors declare no conflict of interest.

\section{Nomenclature}

$\begin{array}{ll}\mathrm{SH} & \text { Sunflower husk } \\ \mathrm{SHP} & \text { Sunflower husk pellets } \\ \mathrm{HP} & \text { Hardwood pellets } \\ \mathrm{HHV} & \text { Higher heating value of the fuel }(\mathrm{MJ} / \mathrm{kg}) \\ \mathrm{T}_{\text {flame }} & \text { Averaged flame temperature }\left({ }^{\circ} \mathrm{C}\right) \\ \mathrm{T}_{\mathrm{MAX}} & \text { Maximum combustion temperature }\left({ }^{\circ} \mathrm{C}\right) \\ \mathrm{v}_{\mathrm{t}} & \text { Temperature front velocity }(\mathrm{mm} / \mathrm{min}) \\ \mathrm{v}_{\mathrm{C}} & \text { Combustion front velocity }(\mathrm{mm} / \mathrm{min}) \\ \mathrm{v}_{\mathrm{m}} & \text { Mass loss rate }(\mathrm{g} / \mathrm{min}) \\ \mathrm{F}_{\text {out }} & \text { Fuel consumption density }\left(\mathrm{kg} / \mathrm{s} \cdot \mathrm{m}^{2}\right) \\ \mathrm{P}_{\rho} & \text { Power output density }\left(\mathrm{MW} / \mathrm{m}^{2}\right) \\ \mathrm{T}_{1}-\mathrm{T} 4 & \text { Thermocouple } 1-4 \\ \mathrm{~A}_{\mathrm{g}} & \text { Surface area of the grate }\left(\mathrm{m}^{2}\right) \\ \rho \mathrm{\rho bulk} & \text { Bulk density of the fuel bed }\left(\mathrm{kg} / \mathrm{m}^{3}\right)\end{array}$




\section{References}

1. Yanik, J.; Duman, G.; Karlström, O.; Brink, A. $\mathrm{NO}$ and $\mathrm{SO}_{2}$ emissions from combustion of raw and torrefied biomasses and their blends with lignite. J. Environ. Manag. 2018, 227, 155-161. [CrossRef]

2. Lynch, D.; Henihan, A.M.; Bowen, B.; Lynch, D.; McDonnell, K.; Kwapinski, W.; Leahy, J.J. Utilisation of poultry litter as an energy feedstock. Biomass Bioenergy 2013, 49, 197-204. [CrossRef]

3. Lundgren, J.; Pettersson, E. Combustion of horse manure for heat production. Bioresour. Technol. 2009, 100, 3121-3126. [CrossRef] [PubMed]

4. Hao, Z.; Yang, B.; Jahng, D. Combustion characteristics of biodried sewage sludge. Waste Manag. 2018, 72, 296-305. [CrossRef]

5. Kijo-Kleczkowska, A.; Środa, K.; Kosowska-Golachowska, M.; Musiał, T.; Wolski, K. Combustion of pelleted sewage sludge with reference to coal and biomass. Fuel 2016, 170, 141-160. [CrossRef]

6. Ronda, A.; Gomez-Barea, A.; Haro, P.; de Almeida, V.F.; Salinero, J. Elements partitioning during thermal conversion of sewage sludge. Fuel Process. Technol. 2019, 186, 156-166. [CrossRef]

7. Vamvuka, D.; Sfakiotakis, S. Combustion behavior of biomass fuels and their blends with lignite. Thermochem. Acta 2011, 192-199. [CrossRef]

8. Zheng, S.; Yang, Y.; Li, X.; Liu, H.; Yan, W.; Sui, R.; Lu, Q. Temperature and emissivity measurements from combustion of pine wood, rice husk and fire wood using flame emission spectrum. Fuel Process. Technol. 2020, 204, 106423. [CrossRef]

9. Zeng, T.; Pollex, A.; Weller, N.; Lenz, V.; Nelles, M. Blended biomass pellets as fuel for small scale combustion appliances: Effect of blending on slag formation in the bottom ash and pre-evaluation options. Fuel 2018, 212, 108-116. [CrossRef]

10. Van, L.S.; Koppejan, J. The Handbook of Biomass Combustion and Co-Firing; Earthscan: London, UK, 2008.

11. Ríos-Badrán, I.M.; Luzardo-Ocampo, I.; García-Trejo, J.F.; Santos-Cruz, J.; Gutierrez-Antonio, C. Production and characterization of fuel pellets from rice husk and wheat straw. Renew. Energy 2020, 145, 500-507. [CrossRef]

12. Pradhan, P.; Mahajani, S.M.; Arora, A. Production and utilization of fuel pellets from biomass: A review. Fuel Process. Technol. 2018, 181, 215-232. [CrossRef]

13. Labbé, R.; Paczkowski, S.; Knappe, V.; Russ, M.; Wöhler, M.; Pelz, S. Effect of feedstock particle size distribution and feedstock moisture content on pellet production efficiency, pellet quality, transport and combustion emissions. Fuel 2020, $263,116662$. [CrossRef]

14. Monedero, E.; Portero, H.; Lapuerta, M. Pellet blends of poplar and pine sawdust: Effects of material composition, additive, moisture content and compression die on pellet quality. Fuel Process. Technol. 2015, 132, 5-23. [CrossRef]

15. Nielsen, S.K.; Mandø, M.; Rosenørn, A.B. Review of die design and process parameters in the biomass pelleting proces. Powder Technol. 2020, 364, 971-985. [CrossRef]

16. Perea-Moreno, M.A.; Manzano-Agugliaro, F.; Perea-Moreno, A.J. Sustainable Energy Based on Sunflower Seed Husk Boiler for Residential Buildings. Sustainability 2018, 10, 3407. [CrossRef]

17. Havrysh, V.; Kalinichenko, A.; Mentel, G.; Mentel, U.; Vasbieva, D.G. Husk Energy Supply Systems for Sunflower Oil Mills. Energies 2020, 13, 361. [CrossRef]

18. Bilandzija, N.; Voca, N.; Jelcic, B.; Jurisic, V.; Matin, A.; Grubor, M.; Kricka, T. Evaluation of Croatian agricultural solid biomass energy potential. Renew. Sustain. Energy Rev. 2018, 93, 225-230. [CrossRef]

19. Quaranta, N.; Unsen, M.; López, H.; Giansiracusa, C.; Roether, J.A.; Boccaccini, A.R. Ash from sunflower husk as raw material for ceramic products. Ceram. Int. 2011, 37, 377-385. [CrossRef]

20. Ooi, T.C.; Aries, E.; Ewan, B.C.R.; Thompson, D.; Anderson, D.R.; Fisher, R.; Fray, T.; Tognarelli, D. The study of sunflower seed husks as a fuel in the iron ore sintering process. Miner. Eng. 2008, 21, 167-177. [CrossRef]

21. Barczewski, M.; Sałasińska, K.; Szulc, J. Application of sunflower husk, hazelnut shell and walnut shell as waste agricultural fillers for epoxy-based composites: A study into mechanical behavior related to structural and rheological properties. Polym. Test. 2019, 75, 1-11. [CrossRef]

22. Kułażyński, M.; Jabłoński, S.; Kaczmarczyk, J.; Świątek, Ł.; Pstrowska, K.; Łukaszewicz, M. Technological aspects of sunflower biomass and brown coal co-firing. J. Energy Inst. 2017, 91, 668-675. [CrossRef]

23. Bala-Latwiniak, A.; Zajemska, M. Computational and experimental study of pine and sunflower huskpellet combustion and co-combustion with oats in domestic boiler. Renew. Energy 2020, 62, 151-159. [CrossRef]

24. López, R.; Fernández, C.; Fierro, J.; Cara, J.; Martínez, O.; Sánchez, M.E. Oxy-combustion of corn, sunflower, rape and microalgae bioresidues and their blends from the perspective of thermogravimetric analysis. Energy 2014, 74, 845-854. [CrossRef]

25. Kluska, J.; Turzyński, T.; Kardaś, D. Experimental tests of co-combustion of pelletized leather tannery wastes and hardwood pellets. Waste Manag. 2018, 79, 22-29. [CrossRef] [PubMed]

26. Verma, V.K.; Bram, S.; Delattin, F.; Laha, P.; Vandendael, I.; Hubin, A.; de Ruyck, J. Agro-pellets for domestic heating boilers: Standard laboratory and real life performance. Appl. Energy 2012, 90, 17-23. [CrossRef]

27. Cardozo, E.; Erlich, C.; Alejo, L.; Fransson, T.H. Combustion of agricultural residues: An experimental study for small-scale applications. Fuel 2014, 115, 778-787. [CrossRef]

28. Kougioumtzis, M.A.; Kanaveli, I.P.; Karampinis, E.; Grammelis, P.; Kakaras, E. Combustion of olive tree pruning pellets versus sunflower husk pellets at industrial boiler. Monit. Emiss. Combust. Effic. Renew. Energy 2021, 171, 516-525. [CrossRef] 
29. Llorente, M.J.F.; Garcia, J.E.C. Comparing methods for predicting the sintering of biomass ash in combustion. Fuel 2005, 84, 1893-1900. [CrossRef]

30. Svoboda, K.; Pohořelý, M.; Hartman, M.; Martinec, J. Pretreatment and feeding of biomass for pressurized entrained flow gasification. Fuel Process. Technol. 2009, 90, 629-635. [CrossRef] 